\title{
Obituary
}

\section{Dr Zuhair Hallaj, 1941-2016}

It is with great sadness that friends and colleagues all over the world learn of the passing away of Dr Zuhair Hallaj on 19 June 2016, following a protracted illness that he fought with courage and determination.

Dr Hallaj was born in January 1941 in Lattakia, Syria. He graduated from Cairo University in 1965 and got his doctorate in epidemiology from the High Institute of Public Health, Alexandria University in 1972. After twenty years of intense public health work in Syria, where he directed the Department of Public Health at the University of Aleppo from 1973 to 1979, and the Faculty of Medicine at Tishreen University in his native Lattakia from 1980 to 1991, Dr Hallaj joined WHO/EMRO in Alexandria in 1994 as Regional Adviser on Emerging Communicable Diseases. Afterwards, he served as WHO Representative in Egypt from 1999 to 2008 and at the same time he was appointed Director of the EMRO's Division of Communicable Disease Control from 2000 to 2008. In his later years, Dr Hallaj was appointed as special adviser to WHO Regional Director for the Eastern Mediterranean in the area of Communicable Disease Control and Epidemiology and provided high-level advice and consultancy to Ministries of Health and

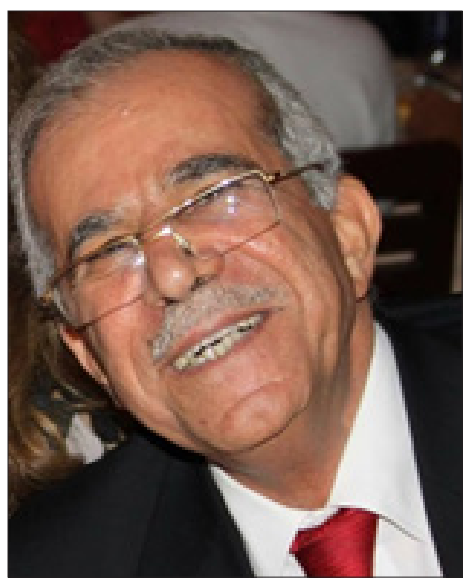
international organizations involved in health protection and promotion.

Dr Zuhair Hallaj's impact upon health is memorable in Syria and EMR countries. He established principles and practice of public health, preventive medicine and epidemiology in the Region. He will be remembered for his vast strategic vision encompassing all domains of public health and for his ability to formulate science-based policies and translate them into concrete and practical actions.

Dr Hallaj supervised and coordinated efforts to combat a wide range of infectious diseases, including tuberculosis, malaria, measles, parasitic infections and zoonotic diseases. He ably and firmly supervised the multi-sectoral efforts to address epidemics that emerged or re-emerged at the turn of the third millennium including severe acute respiratory syndrome (SARS), avian influenza, swine influenza and the Middle East respiratory syndrome coronavirus (MERS-CoV).

His memory will live among those who knew him because of his warm smile, pleasant personality, presence that spreads warmth around with his sincere affection and friendly feelings coupled with hope and optimism and his conversations which combined rigour of science with anecdotes and lessons learnt from remote and recent history.

Dr Hallaj will always be remembered by the successive generations of his students, colleagues, kith and kin whose practice will immortalize his name.

الدكتور زهير صبحي حلاج 1941-2016

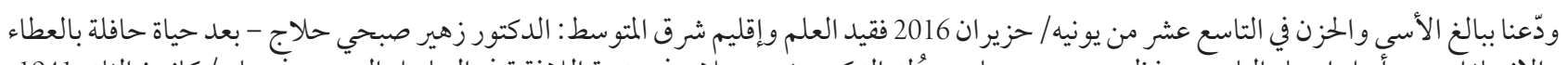

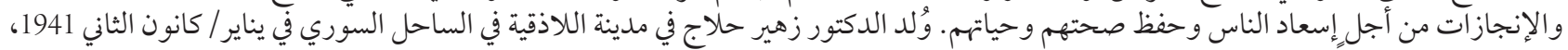

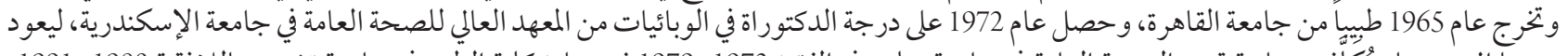

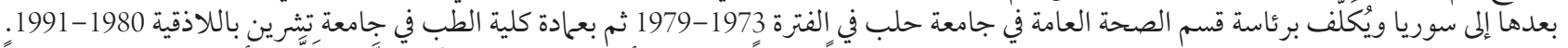

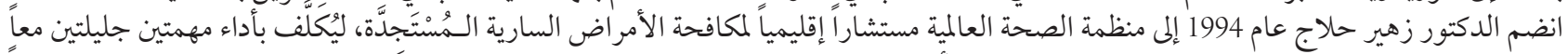

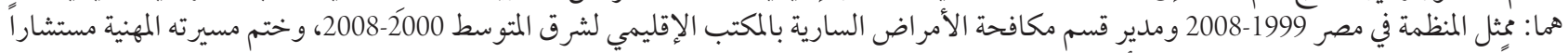

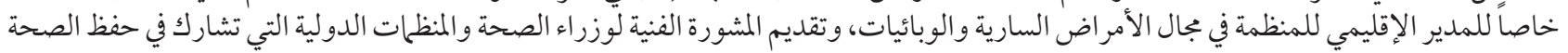

وللدكتور حلاج - رحمه الله - بصمات لاتمحى في سوريا وبلدان إقليم شرق المتو سط، فقد رسَّخ أصول و وممارسات الصحة العامة والطب الطب الو قائي و الوبائيات

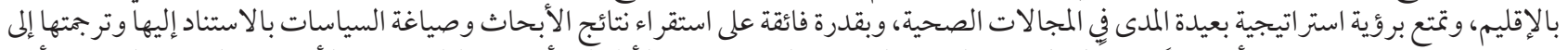

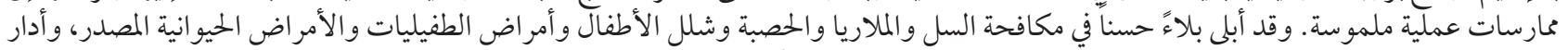

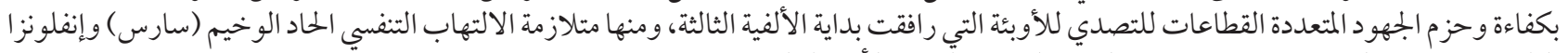

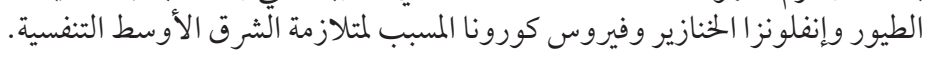

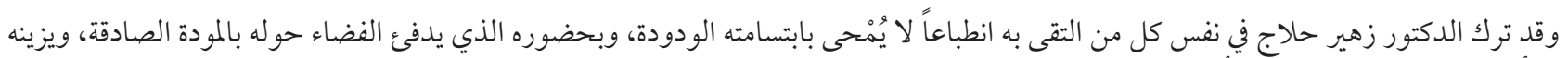

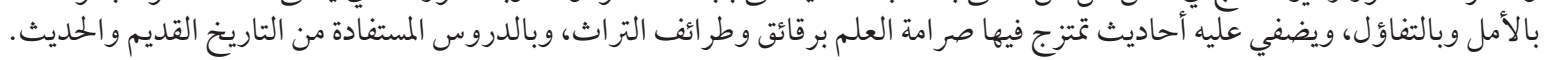

$$
\text { سيبقى الدكتور زهير حلاج حاضراً في أذهان وممارسات الأجيال المتعاقبة من طلابه وزملائه وأهله وذويه. }
$$

